\title{
Interculturality: In Search of a New Global World Project
}

\author{
Olga Bondar \\ Department of Social Philosophy \\ Faculty of Humanities and Social Sciences \\ Peoples Friendship University of Russia \\ 6 Miklukho-Maklaya st., Moscow, 117198 \\ Moscow, Russia \\ E-mail: bondar_oyu@pfur.ru
}

\begin{abstract}
The author provides a critical analysis of the neoliberal globalization model in the context of its contrast to the intercultural model of a global world.
\end{abstract}

Keywords-interculturality; neoliberal globalization; $R$. Fornet-Betancourt

\section{INTRODUCTION}

Globalization processes of the late 20th - beginning of 21 st centuries, startling by their scope and intensity on macro- and microlevels, set a wide a range of actors involved. The international community has morphed into a new form of coexistence, planetary-universal and integrative in its nature.

A new quality of social existence universality ceased to fit into the casual framework of national state formations. The result was their internal space re-engineering. The disintegration of the "unholy Trinity" (Z.Bauman) - the loss of the "nation - territory - state" unity - resulted in complication of political processes and involvement of the new actors, the dependence of the national economies from the world economy, the invasion of the Other cultures into the local cultural "soil", the social conflicts etc.

The emerging interaction types in a globalizing world show no counterparts in history and social experience. That means that subjects of globalizing world have no value basis and no common communication strategy.

Hence the task for philosophical analysis: to comprehend the essence of globalization processes at the current stage, to identify problems caused by it and to design functional solutions. Of particular interest in this context are the concepts created by the non-Western authors, representing those local civilizational formations that are defined as "periphery" or "the Third World" in the scientific literature. However, before we present those explanatory models, let us outline the problematic field of globalization.

\section{TO THE REVERSE SIDE OF GLOBALIZATION PROCESSES}

The complexity of the current stage globalization development processes encourages the scholars to interpret it basing on their academic interests. The desire to review the globalization through the prism of their own disciplinary affiliation reduces the complexity to one-dimensional measurement. Yet some researchers [cf. 1, e.g.] prove that it would be inappropriate to reduce the global processes to monocausality. Globalization is framed by the development "logic". Nowadays we have to discuss the political, cultural, informational etc. globalization along with the established model of the economical one.

It would be wrong to assume that at the current stage the globalization processes meet no complications. Their roots are found in the temporal multidimensionality of the modern world and thus in the variety of the participants' potentials that increases their proneness to conflict. Thus emerge the definitions of the modern world as "diversity without unity" (M.Albrow) or "archipelago of diasporas" (Z.Bauman).

The "wealth - poverty" connection serves as an intensifying factor of the development processes contradictions. The gap in the level of economic growth and social well-being, caused by the neoliberalism domination, lays the foundation for excluding the marginalized subjects from the modern life currents. This exclusion in its extreme forms may result in emergence of a "structurally superfluous man" - a poor person who is "useless from every given point of view" (Z.Bauman) [cited by: 1, P. 106]. The victory of capital over the private, national, state etc. interests raises the question of legitimacy of the existing dominant economical system and leads to the emergence of the judgmental groups - alter-globalists, that view their purpose in search of an alternative global processes development model.

\section{NEOLIBERAL GLOBALIZATION IN THE LIGHT OF ITS CONSEQUENCES}

The Cuban scholar Raul Fornet-Betancourt aims an intercultural world project to identify and mitigate the 
consequences of the worldview formed under the influence of neoliberalism. Focusing on a critique of consequences of neoliberal expansion in anthropological and cosmological spheres, he draws a number of crucial conclusions, that may be conceptualized the following way.

\section{A. The Anthropological Aspect}

The globalization processes dragged neoliberalism out and beyond the economical system, subordinating it to the social market laws. The "market" interpretation of social relations emerged: social actors are regarded as free entrepreneurs, their life as a company and social interaction as a contract.

Neoliberal globalization, defining the development processes, educates and creates the subjects essential for itself - the bearers of its "spirit". The description of human life in economic terms - "cost", "increment", "market", etc. transforms the knowledge sphere regarding a human being. Hence the general anthropology is being replaced by the "subject contract" anthropology, the purpose of which is the pursuit of efficiency, maximizing the possibilities of appropriation, hedonism and consumerism.

Hegemony of neoliberalism has also changed a human's perception of historical time, denying its duration, turning it into "clock-face", something calculable. Historically unrooted human being, turned into a system sector with colonized subjective fields, presents a threat of anthropological inversion - the emergence of a person, ultimately tearing the ties to the humanistic tradition [cf.: 2, P. 41] allowing him to fulfill himself as a Human.

\section{B. The Cosmological Aspect}

Let us consider the interpretative models, revealing, what is a universe, that arise in the context of neoliberal strategies and how the existence of modern man and the world itself depend on them.

Neoliberalism, matching in nature and vector with globalism, attains in its field the sustainable existence forms via informational-communicative technologies, supporting and developing the main idea - the intensification and total distribution of the free market, covering all the international horizon and piercing into all the public life spheres.

The anthropological quest or the turn of man to himself, moved by the spirit of non-liberal globalization, shows no cognitive or moral-ethical approach, but is rather determined by the issue of satisfying hedonism and vitality, that are on the rise under economic dependance. From R.FornetBetancourt's standing, the emerging correlation between the worldview, shaped by the spirit of forming neoliberalism, and the "subject contract" anthropology, has the prerequisite character - any other anthropology is possible insofar as there is a different worldview.

Caused by neoliberal strategies, the change in comprehending what is humane and attitude towards it led, according to the philosopher, to the following:
First, to the replacement of "organic cosmos horizon, encouraging us to be universal by rooting in it; planned strategy of ageless world globality, writing its own biography across the horizontal space with the quill of industry";

Second, to the replacement of "experience of the world in its natural slowness and inherent peace, advertisement of telegenic world, depleting because of the instantly fleeing images" [2, P. 42]. The complexity of the processes and issues brought to life by neoliberalism creates a need for these effects interpretation.

\section{The First Consequence}

Anthropocentric revaluation of attitude towards the world, weakened it ontologically which led to its deteleologisation. Rejection of "qualitative" view of the universe was the destruction of universality of the cosmic whole as basic foundation of all its levels and processes of its organization. Rationality, economic efficiency expelled humane, soulful, meaningful life. Impaired world was at the mercy of industry that, imploding and pressing the sphere of existence, turned it into the plane.

Anthropocentrism institutionalized a human being out of (universal) world structures, made human existence acosmical. By losing the unity with cosmos, a subject has not lost neither idea of cosmos, nor the idea of universality, transferring them into the plane of social existence, designing them in the form of isolated spheres - "cosmoses" (M.Weber). As for the economy as a particular case of cosmos, its versatility was formed in the context of the Age of Discovery integration processes and of Modernization, both of which had broken the boundaries of the once dense worlds, paved the way for "cosmopolitization of production and consumption" (K.Marx).

In turn, globalization has transformed the boundaries of isolated spheres (cosmoses) into permeable membranes with controllable currents of exchange and has also expanded the world market outlook by integrating new areas and niches, which hold the processes of self-renewal. There are new techniques of capital accumulation found in areas that didn't lend themselves to calculation and were not profitable from the point of view of commerce and exploitation.

Neoliberal economics globalization transferred the cultural sphere to the market of goods production, seizing the "raw materials" from local cultures, resulting in global "symbols gaining vividness, intensity, ready to be sold" [cf.: 2, P. 87]. Neoliberalism picks only commercially efficient elements of cultural traditions and forms a market for selling them.

Culture, colonized and subordinated to the economic growth, loses its historical and national essence, turns into an artifact: its authenticity is being staged, tradition being made, semantic components being removed and replaced. Costeffective, visually spectacular and unconscious symbols, not really historically significant, are being synthesized into patterns, that create telegenic image of the world that had not 
experienced neither humane tragedies, nor pain from colonial wounds.

The expansion of the neoliberal cultural sphere undergoes not only and not so much as standardization and unification, but as universalization, driven by its transgressive ability to push and cross boundaries, to pierce local cultures contexts and to recreate them from inside "in the way of its desire" (M.Gefter). Universality maintains its principle of omniety, but is revealed through in the form of a universally available culture, being offered for sale at a reasonable price in any given context. The neoliberal biotope is the local variety. The elimination of the said ideological reservoir and raw resources would mean the end of the market and, consequently, the end of the profit.

The market indifference towards local cultures identities and historical memories designs a new concept of the world as a construct, created by global processes and economic strategies. Neoliberalism with its constitutive principle of uprooting the local cultures from their soil, changes the ontological status of cultural polymorphic matrices and sets their instrumental fictitious character. The world as a construct exists disregarding the storage of memories and identities and in its alienation is placed outside of history.

The formula "rise of income and expenses decrease" shrinks the world space and normalizes time. "In economic terms the globe is not huge and vast anymore; it has condensed and became small due to the market, unitized by telecommunications network" [1, P. 44]. As for the narrative, identifying the very existence of the world, it is being created by the biographies of products in the areas of logistics, improving its movement in the branching network of industries.

\section{The Second Consequence}

The neoliberal market, swollen due to the "involvement" of local economies in the global system, relying on the informational communicative segment, strengthened its practices of influence and profit extraction by changing the permissible borders of "(...) transformation of products and phenomena into the buy/sell objects" [3, P. 224]. These processes have expanded the concept of "capital", giving agility to its limits: the methods of concentration and the possibility of converting the cultural, symbolic, human resources now complement the material resources and the mechanics of their accumulation.

Globally operating advertising by increasing the speed of production and consumption, supports the economic activity. Acting from outside, changing each other ads, instantly shape needs. In those ads life is filled with meaning, new desires are awoke and freedom is vested with authenticity.

Designed "single commodity world", serving as an applique work, holding the "united world" concealed, replaces its life and semantic content with multiplying contexts of consumption, narrowing the richness of the world, given to an individual.

An individual, included in those contexts, loses his ontological component. His ability to understand the world around and himself as a being-in-the-world is being replaced by immersion and absorption of discrete streams of images, symbols and scenes - "illusions of places", devoid of semantic unity, yet encouraging the reproduction of their content in the everyday life practices.

Neoliberalism reduces human existence to its economic activity - "I buy, therefore I am" (D.Harvey). This selfreflection eliminates the understanding of the world as the condition of possibility of openness of the world towards an individual. The world is veiled from an individual while an individual is alienated from the world. The world is a market's appendage and an individual, as a consumer, becomes either an alienated tourist (Z.Bauman) or a spectator (Guy Debord).

Neoliberal globalization model has expanded the historical variability of anthropological models with the "subject contract" and, dismantling its human and cosmic essence, put on the relativity basis the value of the humanitarian component.

\section{INTERCULTURALITY AS A RESPONSE TO THE GLOBAL Challenge of NeOLiberalism}

Interculturality, just as a neoliberal globalization model, is a world-design project, but it is distinguished by a humanistic direction of global processes. It is aimed at the creation of humankind in a living world - equilibrium of polyvalent elements of a universe. The intercultural project is expected to prevent the destructive processes stemming from the neoliberal power practices, imposing a virtual image of the world as the only possible one.

Starting from R.Fornet-Betancourt's interpretation of interculturality, we may outline its semantic field in the following aspects.

Interculturality is a gradual process of the world universalization. This becoming of "the world as the world" shows organic forms and, like all things natural, flows slowly, gradually. Interculturality, capturing an individual in his inseparable unity with the world, adds true globality to the process. The world has no other ways to manifest itself, except the one, given to it in the forms and contents of human life, then it makes a return.

A necessary condition for supporting this project is, according to the philosopher, "the restoration of the world's and human's age". Released to the world individual returns the past and keeps it in present in many memories about the open wounds, derived from the development forms being imposed by a particular civilizational model. They have witnessed bygone experiments, revealing the interculturality's true nature and thus requiring reflection.

Interculturality connects the emergence of reality to the cultures' narrative. It reveals the possibilities of the reality in the cultural memories' moduses in their contrast to the market strategies, that design reality for self-legitimization, supplementing it with ahistoricity, placelessness, forgetfulness. In the memories' spaces - myths, legends "cultures tell their secrets, offering to save what funds the 
meaning and distributes the balance" [2, P. 43]. Following R.Fornet-Betancourt's logic, a-, prelogical, irrational content of a mystery should not cause neither a fear of misunderstanding the other culture, nor the fear of being unexplored, unidentified. Interculturality takes as its basis an assumption - "the rule of agnosticism" (E.Holenstein) - that there are mysteries in and among cultures, that will never be solved. We must be prepared that the answers would not be found [5, P.159].

The cultural memory space is organized around the pulses of past, beating in a living tissue of present in the form of significant symbols, defining what is "Ours". In the said "Ours" the meaning of the "basis" is strengthened, "Us" is getting actualized; in or through that concept we find the faces of the world. For R.Fornte-Betancourt the cultural diversity is in the various "alphabets", the knowledge of which allow us to read the world and history [6, P. 11]. However, for this dialogue of cultural memories to take place, one shall acknowledge own intercultural illiteracy and to eliminate it with intercultural "alphabetization", i.e. with the understanding that the terms, set by our tradition and used for naming, referring, are contextual and shall be reconsidered on the assumption of perspectives, opened to us by the concepts of other cultural traditions.

For the philosopher, the emergence of reality, in which interculturality will find its place is possible, but with the support of the intercultural practice. It should also serve as a basis for the emergence of a culture of intercommunication. Interculturality shall initiate a formation of a global world culture both in action and communication, supporting spatial and temporal horizons of the cultural universes in the state of their openness to "the infinity symbol, that is the relationship with the otherness of the other cultural memory" [2, P. 44].

Arguing that "there is no religion without culture, as there is no dialogue of religions without the dialogue of cultures", R.Fornet-Betancourt considers interculturality's ability to carry out the reconfiguration of culture's and religion's dialogue. We are talking here about the necessity to start and support the dialogue of not only cultural, but also religious traditions - "the sources of life and action". "Dialogue appeal" serves as a foundation of interreligious dialogue practices. This appeal is rooted in the "golden rule of morality", yet interpreted in a religious context, and thus reads: "treat the other (other sanctities) the way you want yours (your sanctities - italic and comments by O.B.) to be treated". From R.Fornet-Betancourt's position, exactly the dialogue of religions shall balance the entire space of intercultural dialogue. Otherwise, the dialogue cannot be acknowledged.

Interculturality doesn't dogmatize cultural and religious differences. Contributing to the realization of their needs, motivating their recognition, it strives to create conditions for the "differences to live in dialogue and solidarity, i.e. peace" [6, P. 97].

The process of reality creation, initiated by interculturality, requires to reorganize existing political practices and to review the cultural conventions. Intercultural world is a specific expression of the world in its situation and reality, and not a way to manifest the will to establish peace. It is a balanced, polycentric dialogue space of positive integration, in which cultural differences find their promotion through preservation and maintenance of "otherness", "strangeness", serving as a source for enriching "our" cultural traditions.

\section{CONCLUSION}

R.Fornet-Betancourt's ideas conceptualization allows to see the practical use of the project suggested, that is to identify standards of comprehending the world order, set by the neoliberal market practices, and to stress the issue, whether neoliberalism has the right to single-handedly determine the fate of humanity and its habitat.

Strategic opportunities for intercultural practice shall be taken into consideration not only and not so much from the standpoint of resolution of the existing intercultural problems and conflicts, but from the possibilities of their prevention in the future.

\section{REFERENCES}

[1] Beck U. What is Globalization? Errors of Globalism - Answers to Globalization. M., 2001.

[2] Fornet-Betancourt R. Interculturality and Neoliberal Globalization (translated from Spanish by Bondar O.) // The Dialogue of Civilizations as Vocation. M., 2007.

[3] Harvey D. A Brief History of Neoliberalism. The Actual Readings. M., 2007.

[4] Hösle V. Philosophy and Ecology. M., 1993.

[5] Stepanyants M.T. From Eurocentrism to Intercultural Philosophy // Questions of Philosophy. - 2015. - №10. - P.150-162.

[6] Fornet-Betancourt R. Filosofar para nuestro tiempo en clave intercultural. Aachen, 2004. 